\title{
BIOAKTIVITAS ANTIBAKTERI FRAKSI ODS SPONS Agelas sp. DARI PERAIRAN PULAU BUNAKEN
}

\author{
(ODS Fraction Antibacterial Bioactivity of Agelas sp. Sponge \\ Collected from Bunaken Waters)
}

\section{Luissandy $^{1 *}$, Deiske A. Sumilat ${ }^{1}$, Rosita A. J. Lintang ${ }^{1}$}

1. Program Studi IImu Kelautan Fakultas Perikanan dan IImu Kelautan Universitas Sam

Ratulangi, Manado.

*e-mail : luissandy28@gmail.com

\begin{abstract}
The aims of this research are to get sponge crude extract of Agelas sp. from Bunaken Island waters then fractionated by reversed phase column chromatography technique into 6 fractions with the solvents combination $\mathrm{dH}_{2} \mathrm{O}: \mathrm{CH}_{3} \mathrm{OH}$ and analyzed the antibacterial bioactivity of ODS sponge fraction against the growth of Escherichia coli and Staphylococcus aureus bacteria using disc diffusion method from Kirby and Bauer. The final result of this study showed that fractions 1-5 had antibacterial bioactivity against $E$. coli and $S$. aureus and fraction 6 had no activity, and the two fractions had the highest activity with the diameter of inhibition zone ie fraction 1 with diameter $(18,0 \mathrm{~mm})$ and fraction $2(18,3 \mathrm{~mm})$ against $E$. coli bacteria and for $S$. aureus the inhibition zone diameter of fraction $1(17,0 \mathrm{~mm})$, and fraction $2(16,7 \mathrm{~mm})$. This research showed the Agelas sp. sponge is a potential organism to be expended as antibacterial drug candidate.
\end{abstract}

Keywords: sponge, Agelas sp., antibacterial, column chromatography, octadecyl-silica.

Penelitian ini bertujuan untuk mendapatkan ekstrak kasar spons Agelas sp. dari Perairan Pulau Bunaken lalu difraksinasi dengan teknik reversed phase kromatografi kolom menjadi 6 fraksi dengan kombinasi pelarut $\mathrm{dH}_{2} \mathrm{O}: \mathrm{CH}_{3} \mathrm{OH}$ kemudian menganalisis bioaktivitas antibakteri dari fraksi ODS spons terhadap pertumbuhan bakteri E. colidan S. aureus menggunakan metode difusi agar (disc diffusion Kirby and Bauer). Hasil akhir dari penelitian ini yaitu fraksi 1-5 memiliki bioaktivitas antibakteri terhadap E. coli dan S. aureus dan fraksi 6 tidak memiliki aktivitas, dan dua fraksi diantaranya memiliki aktivitas tertinggi dengan diameter rata-rata zona hambat yaitu fraksi 1 dengan diameter $(18,0 \mathrm{~mm})$ dan fraksi $2(18,3 \mathrm{~mm})$ terhadap bakteri $E$. coli dan untuk $S$. aureus diameter zona hambat fraksi 1 yaitu $(17,0 \mathrm{~mm})$, dan fraksi $2(16,7 \mathrm{~mm})$. Melalui hasil yang diperlihatkan, senyawa bioaktivitas antibakteri fraksi ODS spons Agelas sp. adalah senyawa aktif yang bersifat sedang dan berpotensi sebagai kandidat obat antibakteri.

Kata kunci: spons, Agelas sp., antibakteri, kromatografi kolom, octadecyl-silica.

\section{PENDAHULUAN}

Perairan laut di Indonesia tidak hanya berfungsi sebagai cadangan sumber air di dunia, habitat untuk berbagai jenis biota, dan bahan makanan dari berbagai ragam biota laut, tetapi juga sebagai sumber bahan pembuatan kosmetik dan obat-obatan yang berasal dari Perairan Bunaken, salah satu sumberdaya yang dimiliki dan berpotensi untuk dikembangkan adalah organisme spons. Hewan tersebut turut memberikan kontribusi yang penting terhadap komunitas bentik laut dan sangat umum dijumpai di perairan tropik maupun sub tropik (Rares, 2015; Haedar et al., 2016).

Spons merupakan salah satu biota laut yang sangat prospektif sebagai sumber senyawa bahan-bahan alami seperti peptida, terpenoid, steroid, asetogenin, alkaloid, halida siklik, senyawa nitrogen dan lain-lain. Senyawa-senyawa ini memiliki aktivitas farmakologis antaralain antifouling, antitumor, antiinflamasi, antivirus, antibakteri, dan 
antimalaria (Bara, 2007; Rompas, 2011; Rahman et al., 2014; Blunt et al., 2015). Munculnya permasalahan resistensi bakteri terhadap beberapa jenis antibiotik menyebabkan adanya berbagai upaya dalam menemukan senyawa yang memiliki aktivitas sebagai antibakteri. Antibakteri adalah zat atau senyawa yang dapat mengganggu pertumbuhan atau bahkan dapat mematikan bakteri dengan cara merusak metabolisme mikroba (Schunack et al., 1990; Madigan, 2005). Salah satu organisme yang sangat berpotensi sebagai sumber antibakteri adalah spons, dimana hewan ini telah menjadi perhatian utama dalam berbagai riset mengenai senyawa bioaktif yang dikandungnya. Spons laut memiliki potensi bioaktif yang sangat besar yaitu selama kurang lebih 50 tahun terakhir ada begitu banyak senyawa bioaktif yang telah ditemukan dari spons (Bara, 2007).

\section{METODE PENELITIAN}

\section{Waktu dan Tempat Penelitian}

\begin{abstract}
Rangkaian kegiatan penelitian yang meliputi pengambilan sampel, pekerjaan di laboratorium, dan penyusunan laporan dimulai sejak bulan November 2016 dan berlangsung hingga bulan Mei 2017. Pengambilan dan preparasi sampel dilakukan di Perairan Pangalisang Pulau Bunaken, sedangkan pengamatan dan analisis data dilakukan di Laboratorium Biologi Molekuler dan Farmasetika Laut Fakultas Perikanan dan Ilmu Kelautan Universitas Sam Ratulangi, Manado.
\end{abstract}

\section{Identifikasi Sampel}

Identifikasi terhadap sampel spons dilakukan dengan cara mengamati morfologi organisme spons berupa bentuk, warna, dan tekstur spons. Pengamatan morfologi organisme spons dilakukan dengan berdasarkan acuan pada website dari www.sponsguide.com.

\section{Alat dan Bahan}

Beberapa peralatan yang digunakan pada penelitian ini, antara lain autoklaf, 1 set rotary vacum evaporator, freezedryer, 1 set alat kromatografi kolom, centrifuge tube, micropipete $(\mu \mathrm{l})$, dan peralatan gelas. Sedangkan untuk bahanbahan pembuatan media B1 dibuat dengan menggunakan pepton, ekstrak daging (meat extract), natrium klorida $(\mathrm{NaCl})$, agar, dan aquades. Serta bahan lainnya seperti spons Agelas sp. (sampel), filter paper, kertas cakram, ODS C-18, etanol dan metanol.

Beberapa peralatan dan bahanbahan seperti filter paper, micropipete, centrifuge tube, agar dextrose kentang, pepton, ekstrak daging (meat extract), dan ODS C-18, diperoleh dari TMPU (Tohoku Medical and Pharmaceutical University, Japan). Alat-alat dan bahan pembuatan media B1 yang digunakan pada pengujian antibakteri ini seperti peralatan gelas dicuci bersih, dikeringkan dan disterilisasi menggunakan autoklaf pada suhu $121^{\circ} \mathrm{C}$ selama kurang lebih 15 menit.

\section{Ekstraksi Spons}

Sampel diekstraksi terlebih dahulu dengan cara spons dipotong-potong kecil untuk dimasukkan ke dalam botol plastik yang sudah berisikan etanol/EtOH sebanyak 250 gram per-botol, kemudian setiap botol yang telah berisikan sampel spons ditandai dengan menempelkan kertas label pada masing-masing botol yang berisikan sampel.

\section{Fraksinasi Ekstrak Spons dengan Kromatografi Kolom}

Sebanyak 5 gram ekstrak spons Agelas sp. diambil dan diencerkan dengan menambahkan sedikit metanol dengan konsentrasi $100 \%$. Setelah itu sampel difraksinasi menggunakan teknik reversed phase kromatografi kolom yang berisikan bahan ODS (Octadecyl-silica) dengan kombinasi pelarut metanol dan aquades $\left(\mathrm{CH}_{3} \mathrm{OH}: \mathrm{dH}_{2} \mathrm{O}\right)$, lalu dibuat stepwise elution/elusi bertahap dari $0 \% \mathrm{CH}_{3} \mathrm{OH}$ dalam $150 \mathrm{ml} \mathrm{dH}_{2} \mathrm{O}$ menjadi $100 \% \mathrm{CH}_{3} \mathrm{OH}$ dan $0 \% \mathrm{dH}_{2} \mathrm{O}$, dengan masing-masing konsentrasi yakni fraksi 1 (0\%:100\%), fraksi 2 (30\%:70\%), fraksi 3 (50\%:50\%), fraksi 4 (65\%:35\%), fraksi 5 (80\%:20\%), dan fraksi 6 (100\%:0 \%).

Untuk pembuatan fraksi-fraksi yaitu diambil 12 gelas erlenmeyer, 6 gelas erlenmeyer dijadikan sebagai wadah fraksi 
1 sampai fraksi 6 , sedangkan 6 gelas erlenmeyer lainnya berfungsi untuk menampung hasil fraksinasi.

\section{Pembuatan Kolom (Packing Column)}

Proses pembuatan kolom meliputi pemasangan gelas kolom pada besi penahan dan disesuaikan letaknya (tidak boleh miring), setelah itu masukkan kapas secukupnya dan diletakkan pada bagian paling bawah kolom, kemudian tambahkan juga ODS (Octadecyl-silica) sebanyak 25 gram.

\section{Pembuatan Media Cair B1}

Media cair B1 dibuat untuk kultur bakteri $E$. coli dan $S$. aureus. Banyaknya masing-masing bahan dalam pembuatan media cair B1 untuk tiap masing-masing erlenmeyer yaitu pepton 0,25 gram, ekstrak daging (meat extract) 0,15 gram, natrium klorida $(\mathrm{NaCl}) \quad 0,15$ gram, lalu dimasukkan ke dalam gelas erlenmeyer dan dilarutkan dalam aquades $/ \mathrm{dH}_{2} \mathrm{O}$ sebanyak $50 \mathrm{ml}$, kemudian dibuat homogen menggunakan magnetic stirrer, setelah itu ditutup dan dibungkus menggunakan kertas aluminium foil untuk diautoklaf pada suhu $121^{\circ} \mathrm{C}$ selama kurang lebih 15 menit (Atlas dan Snyder, 2005).

\section{Pembuatan Media Padat B1}

\begin{abstract}
Pada pembuatan media padat B1 menggunakan bahan-bahan dengan takaran seperti pepton 1 gram, ekstrak daging (meat extract) 0,6 gram, natrium klorida $(\mathrm{NaCl})$ 0,6 gram, agar 3 gram, dimasukkan dalam gelas erlenmeyer dan dilarutkan dalam aquades $/ \mathrm{dH}_{2} \mathrm{O}$ sebanyak $200 \mathrm{ml}$, media padat B1 dibuat sebanyak dua media untuk dua bakteri masingmasing sebanyak $200 \mathrm{ml} /$ erlenmeyer (Atlas dan Snyder, 2005).
\end{abstract}

\section{Kultur Bakteri}

Media cair B1 yang sudah disiapkan sebelumnya, ditambahkan dengan masing-masing bakteri yaitu bakteri $E$. coli dan $S$. aureus. Bakteri diambil menggunakan jarum ose dan dimasukkan ke dalam masing-masing erlenmeyer, kemudian dibungkus dengan kertas alumunium foil dan dibiarkan selama 1x24 jam (Ortez, 2005).

\section{Pembuatan Kontrol Positif dan Negatif}

Kontrol positif dibuat menggunakan obat kapsul Kloramfenikol 250 gram yang dilarutkan dalam $250 \mathrm{ml}$ aquades. Sedangkan kontrol negatif menggunakan pelarut metanol $100 \%$.

\section{Pengujian Bioaktivitas Antibakteri Fraksi ODS Spons}

Pengujian antibakteri Fraksi ODS dari ekstrak spons Agelas sp. pada penelitian ini menggunakan konsentrasi dari tiap Fraksi yaitu $20 \mathrm{mg} / \mathrm{ml}$ dan diambil $50 \mu \mathrm{l}$ menggunakan mikropipet untuk ditotolkan pada setiap kertas cakram. Metode yang digunakan pada penelitian ini adalah difusi agar (disc diffusion Kirby and Bauer Method).

\section{Pengamatan dan Pengukuran}

Pengamatan dapat dilakukan setelah 1x24 jam masa inkubasi berakhir sehingga tepian atau pinggir zona hambat dapat ditetapkan sebagai zona pengukuran diameter. Jika daerah pada sekitaran cakram menunjukkan kepekaan bakteri terhadap antibiotik, bahan antibakteri itulah yang digunakan sebagai bahan uji yang dinyatakan dengan diameter zona hambat.

\section{HASIL DAN PEMBAHASAN}

\section{Pengambilan Sampel di Lapangan}

Berdasarkan hasil identifikasi. Spons yang diperoleh pada penelitian ini memiliki ciri-ciri yaitu bercabang besar, memiliki tekstur lunak, dan berwarna orange. Setelah di-identifikasi, selanjutnya

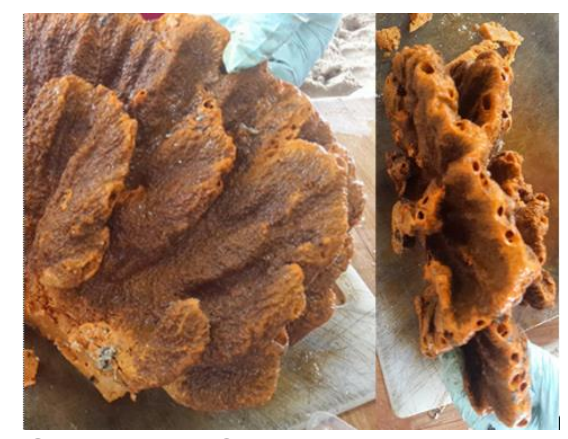

Gambar 1. Spons Agelas sp.

(Dokumentasi pribadi, 2016). 
Tabel 1. Berat botol dan berat basah sampel.

\begin{tabular}{cccc}
\hline No. & $\begin{array}{c}\text { Kode } \\
\text { Sampel/ } \\
\text { Botol }\end{array}$ & $\begin{array}{c}\text { Berat } \\
\text { Botol+Sampel } \\
(\mathrm{gr})\end{array}$ & $\begin{array}{c}\text { Berat } \\
\text { Basah } \\
\text { Sampel } \\
(\mathrm{gr})\end{array}$ \\
\hline $1 . \quad$ PSB1 & $508 \mathrm{gr}$. & $258 \mathrm{gr}$. \\
$2 . \quad$ PSB2 & $529 \mathrm{gr}$. & $279 \mathrm{gr}$. \\
3. $\quad$ PSB3 & $550 \mathrm{gr}$. & $300 \mathrm{gr}$. \\
Total Berat & $1,587 \mathrm{gr}$. & $837 \mathrm{gr}$. \\
Keseluruhan & & \\
\hline
\end{tabular}

spons dipotong-potong berbentuk dadu/kubus, potongan sampel spons dimasukkan ke dalam botol plastik yang berisikan pelarut etanol $(\mathrm{EtOH})$ sebanyak $250 \mathrm{gram} /$ botol yang telah diberi tanda/label terlebih dahulu (PSB1, PSB2, dan PSB3).

\section{Ekstraksi Spons Agelas sp.}

Ekstrak sampel yang telah diperoleh dari maserasi dengan etanol dalam botol, kemudian difiltrasi menggunakan filter paper dan vakum, yang bertujuan untuk memisahkan antara debris dan filtrat sampel. Etanol digunakan karena mempunyai sifat yang selektif, ekonomis, dan mampu mengekstrak sebagian besar senyawa kimia yang terkandung dalam sampel. Berat ekstrak kasar spons hasil evaporasi tersebut diperoleh berat ekstrak sebanyak 6,9656 gram.

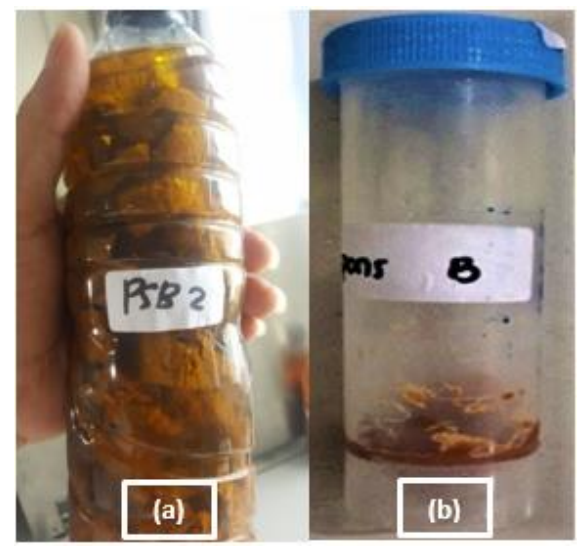

Gambar 2. Sampel sebelum (a) dan setelah dievaporasi (b) (Dokumentasi pribadi, 2016).

\section{Fraksinasi Spons dengan Kromatografi Kolom}

Proses fraksinasi ekstrak sampel spons menggunakan ODS dan kromatografi kolom berlangsung sekitar satu hari, selama pengumpulan fraksifraksi sampel. Untuk mempercepat proses fraksinasi sampel, diperlukan teknik khusus. Pada penelitian ini, proses fraksinasi ekstrak spons menggunakan alat pemompa angin dan selang, hal tersebut bertujuan untuk memberikan tekanan terhadap pelarut/sampel yang masuk ke dalam kolom sehingga proses fraksinasi bisa sedikit lebih cepat.

Berdasarkan hasil fraksinasi, diperoleh 6 fraksi hasil kromatografi kolom dengan warna yang berbeda. 3 fraksi diantaranya memiliki warna yang hampir sama yaitu dengan warna orange pekat yang diperlihatkan fraksi 1 , fraksi 2 , dan fraksi 3, sedangkan fraksi 4 memiliki warna kuning, fraksi 5 berwarna kecoklatan, dan fraksi 6 berwarna kuning terang.
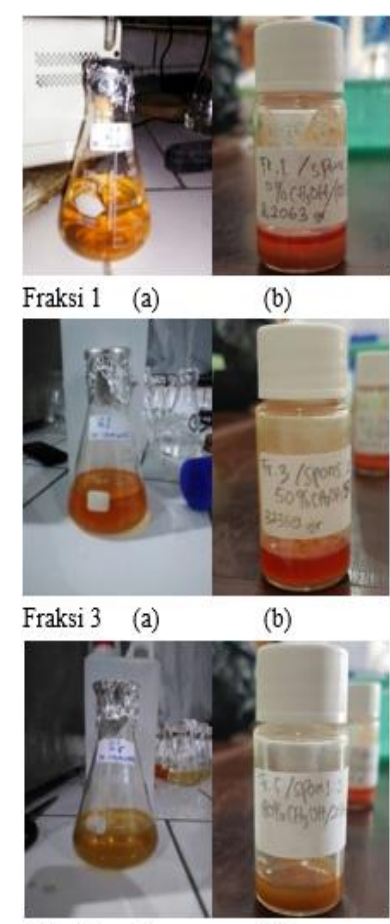

Fraksi 5 (a)
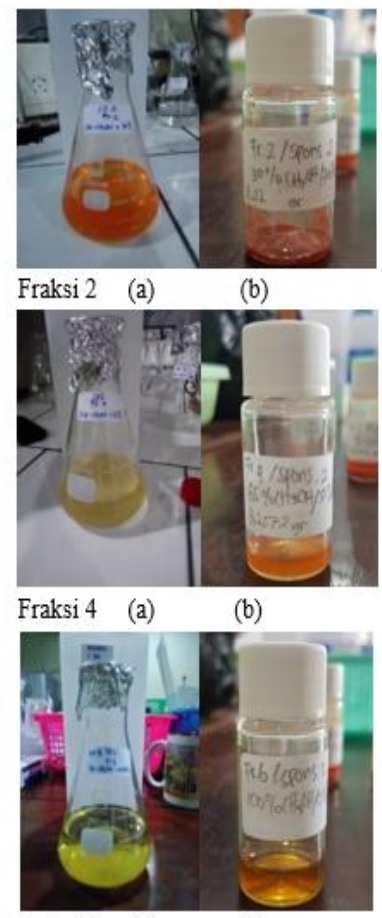

Fraksi 6 (a) (b)
Gambar 3. Hasil fraksinasi spons Agelas sp. dengan kromatografi kolom (a) dan hasil evaporasi kembali fraksi 1-6 (b) (Dokumentasi pribadi, 2017). 
Perbedaan warna dari setiap fraksi ekstrak spons yang diperoleh dari penelitian ini kemungkinan disebabkan karena keragaman kandungan metabolit sekunder spons seperti peptida, terpenoid, steroid, asetogenin, alkaloid, halida siklik, dan senyawa nitrogen lainnya diperkirakan mempengaruhi perubahan warna tersebut, sama halnya dengan kandungan fitokimia. Penelitian yang pernah dilakukan oleh Temidayo (2013) mengisolasi zat fitokimia dengan kromatografi kolom dan memperoleh warna kuning dari salah saturaksi yang terindikasi mengandung senyawa flavonoid.

\section{Evaporasi dan Pengeringan Fraksi- fraksi ODS spons}

Proses evaporasi dari ke-enam fraksi sampel menggunakan waktu yang cukup panjang, khususnya pada fraksi 1 dan 2 dimana konsentrasi pelarut fraksi 1 dan 2 mengandung paling banyak air $/ \mathrm{dH}_{2} \mathrm{O}$ yang menyebabkan proses evaporasi lama. Tingkat adsorpsi komponen senyawa tergantung pada polaritas molekul, aktivitas adsorben, dan polaritas fase gerak cair. Umumnya senyawa dengan gugus fungsional lebih polar akan ter-adsorbi lebih kuat pada permukaan fase padatan dan aktivitas adsorben

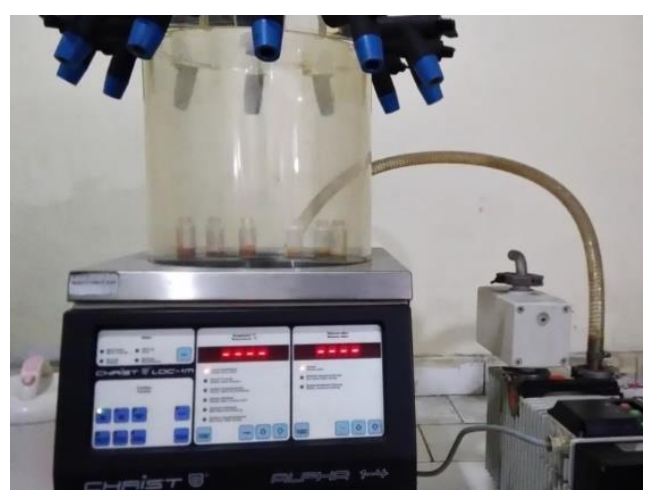

Gambar 4. Proses pengeringan ke-enam fraksi ODS spons Agelas sp. dengan alat freezedryer (Dokumentasi pribadi, 2017).
Tabel 2. Berat kering dari fraksi 1 hingga fraksi 6 .

\begin{tabular}{ccc}
\hline No. & $\begin{array}{c}\text { Fraksi-fraksi } \\
\text { Sampel }\end{array}$ & $\begin{array}{c}\text { Berat Kering Fraksi- } \\
\text { fraksi ODS spons } \\
\text { Agelas sp. } \\
\text { (gram) }\end{array}$ \\
\hline 1. & Fraksi 1 & 3,0925 gram \\
2. & Fraksi 2 & 0,2312 gram \\
3. & Fraksi 3 & 0,1548 gram \\
4. & Fraksi 4 & 0,0231 gram \\
5. & Fraksi 5 & 0,0067 gram \\
6. & Fraksi 6 & 0,0200 gram \\
\hline
\end{tabular}

tergantung komposisi kimianya, ukuran partikel, dan pori-pori partikel (Pedersen dan Myers, 2011; Firmansyah, 2014).

Berat kering fraksi sampel pada penelitian ini didapatkan berat yang bervariasi, tetapi fraksi 1 memiliki berat kering yang paling besar dibandingkan dengan fraksi lainnya. Hal ini mengindikasikan bahwa ekstrask sampel yang digunakan adalah sampel yang mudah larut di air.

\section{Pengujian Bioaktivitas Antibakteri Fraksi ODS Spons}

Dalam penelitian tentang pengujian bioaktivitas antibakteri fraksi ODS spons Agelas sp., hasil dari penelitian ini diperoleh melalui pengamatan yang dilakukan selama 1x24 jam masa inkubasi dengan 3 kali pengulangan untuk masingmasing fraksi terhadap kedua bakteri uji. Terbentuknya zona hambat (daerah bening) di sekeliling kertas cakram menunjukkan kepekaan bakteri terhadap bahan antibakteri maupun antibiotik yang digunakan sebagai kontrol positif (Kloramfenikol). Pengujian dilakukan untuk melihat aktivitas antibakteri dari semua fraksi sampel terhadap bakteri uji $E$. coli dan $S$. aureus. Hasil pengujian bioaktivitas antibakteri sampel, menunjukkan diameter zona hambat fraksi ODS ekstrak kasar spons Agelas sp., dari fraksi 1 hingga fraksi 5, terhadap bakteri E. coli dan $S$. aureus, diameter yang dihasilkan setiap fraksi sampel selanjutnya diukur menggunakan 
Tabel 3. Hasil pengukuran diameter zona hambat dari fraksi ODS spons Agelas sp. terhadap bakteri E. coli.

\begin{tabular}{|c|c|c|c|c|c|}
\hline \multirow{3}{*}{ Fraksi-Fraksi } & \multirow{3}{*}{$\begin{array}{l}\text { Berat kering } \\
\text { Fraksi- } \\
\text { Fraksi }\end{array}$} & \multicolumn{4}{|c|}{$\begin{array}{c}\text { E. coli } \\
\text { Zona hambat }(\mathrm{mm})\end{array}$} \\
\hline & & $\begin{array}{c}\text { Ulangan } \\
1\end{array}$ & $\begin{array}{l}\text { Ulangan } \\
2\end{array}$ & $\begin{array}{l}\text { Ulangan } \\
\quad 3\end{array}$ & Rerata \\
\hline & & \multicolumn{4}{|c|}{$\begin{array}{l}\text { Konsentrasi sampel dalam kertas cakram } \\
\qquad(20 \mathrm{mg} / \mathrm{ml})\end{array}$} \\
\hline Fraksi 1 & 3,0925 gram & $18 \mathrm{~mm}$ & $18 \mathrm{~mm}$ & $18 \mathrm{~mm}$ & 18,0 \\
\hline Fraksi 2 & 0,2312 gram & $18 \mathrm{~mm}$ & $18 \mathrm{~mm}$ & 19 mm & 18,3 \\
\hline Fraksi 3 & 0,1548 gram & $8 \mathrm{~mm}$ & $8 \mathrm{~mm}$ & $8 \mathrm{~mm}$ & 8,0 \\
\hline Fraksi 4 & 0,0231 gram & $8 \mathrm{~mm}$ & $8 \mathrm{~mm}$ & $8 \mathrm{~mm}$ & 8,0 \\
\hline Fraksi 5 & 0,0067 gram & $8 \mathrm{~mm}$ & $8 \mathrm{~mm}$ & $8 \mathrm{~mm}$ & 8,0 \\
\hline Fraksi 6 & 0,0200 gram & 0 & 0 & 0 & 0,0 \\
\hline \multirow{3}{*}{$\begin{array}{l}\text { Kloramfenikol } \\
\text { Metanol (-) }\end{array}$} & - & $28 \mathrm{~mm}$ & $28 \mathrm{~mm}$ & $28 \mathrm{~mm}$ & 28,0 \\
\hline & - & 0 & 0 & 0 & 0,0 \\
\hline & & \multicolumn{4}{|c|}{$\begin{array}{r}\text { Konsentrasi kontrol positif }=250 \mathrm{mg} / \mathrm{ml} \\
\text { Diameter kertas cakram }=6 \mathrm{~mm} \\
\text { Daya serap kertas cakram }=100 \mu \mathrm{l} \\
\text { aknya Fraksi dalam kertas cakram }=50 \mu \mathrm{l}\end{array}$} \\
\hline
\end{tabular}

Tabel 4. Hasil pengukuran diameter zona hambat dari fraksi ODS spons Agelas sp. terhadap bakteri $S$. aureus.

\begin{tabular}{|c|c|c|c|c|c|}
\hline \multirow{3}{*}{ Fraksi-Fraksi } & \multirow{3}{*}{$\begin{array}{c}\text { Berat kering } \\
\text { Fraksi- } \\
\text { Fraksi }\end{array}$} & \multicolumn{4}{|c|}{$\begin{array}{c}\text { S. aureus } \\
\text { Zona hambat }(\mathrm{mm})\end{array}$} \\
\hline & & $\begin{array}{c}\text { Ulangan } \\
1\end{array}$ & $\begin{array}{c}\text { Ulangan } \\
2\end{array}$ & $\begin{array}{c}\text { Ulangan } \\
3\end{array}$ & Rerata \\
\hline & & \multicolumn{4}{|c|}{$\begin{array}{l}\text { Konsentrasi sampel dalam kertas cakram } \\
\qquad(20 \mathrm{mg} / \mathrm{ml})\end{array}$} \\
\hline Fraksi 1 & 3,0925 gram & $17 \mathrm{~mm}$ & $17 \mathrm{~mm}$ & $17 \mathrm{~mm}$ & 17,0 \\
\hline Fraksi 2 & 0,2312 gram & $16 \mathrm{~mm}$ & $18 \mathrm{~mm}$ & $16 \mathrm{~mm}$ & 16,7 \\
\hline Fraksi 3 & 0,1548 gram & 8 mm & $8 \mathrm{~mm}$ & $8 \mathrm{~mm}$ & 8,0 \\
\hline Fraksi 4 & 0,0231 gram & $8 \mathrm{~mm}$ & $8 \mathrm{~mm}$ & $8 \mathrm{~mm}$ & 8,0 \\
\hline Fraksi 5 & 0,0067 gram & $8 \mathrm{~mm}$ & $8 \mathrm{~mm}$ & $8 \mathrm{~mm}$ & 8,0 \\
\hline \multirow{3}{*}{$\begin{array}{l}\text { Fraksi } 6 \\
\text { Kloramfenikol } \\
\text { Metanol (-) }\end{array}$} & 0,0200 gram & 0 & 0 & 0 & 0,0 \\
\hline & - & $27 \mathrm{~mm}$ & $27 \mathrm{~mm}$ & $27 \mathrm{~mm}$ & 27,0 \\
\hline & - & 0 & 0 & 0 & 0,0 \\
\hline \multicolumn{6}{|c|}{$\begin{array}{r}\text { Konsentrasi kontrol positif }=250 \mathrm{mg} / \mathrm{ml} \\
\text { Diameter kertas cakram }=6 \mathrm{~mm} \\
\text { Daya serap kertas cakram }=100 \mu \mathrm{l} \\
\text { aknya Fraksi dalam kertas cakram }=50 \mu \mathrm{l}\end{array}$} \\
\hline
\end{tabular}


mistar dan disalin dalam satuan millimeter (mm).

Bioaktivitas yang diperlihatkan fraksi 1 dan 2 dari ke-dua bakteri uji menunjukkan kesamaan lebar diameter zona hambat, sedangkan dibandingkan dengan fraksi 2 berat kering paling banyak ada pada fraksi 1 . Kejadian ini menyatakan bahwa berat fraksi ternyata tidak memberi pengaruh terhadap kuat atau tidaknya aktivitas fraksi sampel, melainkan karena sifat dari senyawa yang terkandung pada fraksi.

Pengujian terhadap ke-enam fraksi spons Agelas sp., 2 fraksi diantaranya yaitu fraksi 1 dan 2 memiliki bioaktivitas antibakteri yang paling besar, (Gambar 5 dan Gambar 6). Melalui data (Tabel 3 dan Tabel 4), dapat disimpulkan bahwa fraksinasi kromatografi kolom terhadap ekstrak spons Agelas sp. dengan menggunakan kombinasi pelarut $\mathrm{CH}_{3} \mathrm{OH}$ dan $\mathrm{dH}_{2} \mathrm{O}$ menghasilkan senyawa antibakteri yang larut dalam air, seperti yang ditunjukkan fraksi 1 dan 2 yang merupakan larutan dengan konsentrasi air yang tinggi yaitu $100 \% \mathrm{dH}_{2} \mathrm{O}$ (fraksi 1), dan $80 \% \mathrm{dH}_{2} \mathrm{O}$ (fraksi 2) dengan diameter zona hambat 17 dan $18 \mathrm{~mm}$. Sedangkan fraksi lainnya menghasilkan diameter di bawah dari $17 \mathrm{~mm}$, hal ini dikarenakan pelarut yang digunakan sudah memiliki konsentrasi $\mathrm{CH}_{3} \mathrm{OH}$ yang tinggi dan $\mathrm{dH}_{2} \mathrm{O}$ yang rendah.

Melalui data yang ditampilkan pada Tabel 3 dan Tabel 4 menunjukkan bahwa setelah dilakukan pengujian bioaktivitas antibakteri dari ke-enam fraksi ODS ekstrak spons Agelas sp. terhadap bakteri uji $E$. coli dan $S$. aureus maka didapatkan diameter zona hambat yang tidak jauh berbeda. Pengukuran diameter zona hambat terhadap kedua bakteri uji diperlihatkan oleh fraksi 1-5 dari 3 ulangan, tetapi fraksi 6 tidak demikian. Selanjutnya data pengukuran diameter zona hambat pada Tabel 3 dan Tabel 4 dibuat dalam bentuk diagram batang yang disajikan seperti pada Gambar 6 dan Gambar 7.

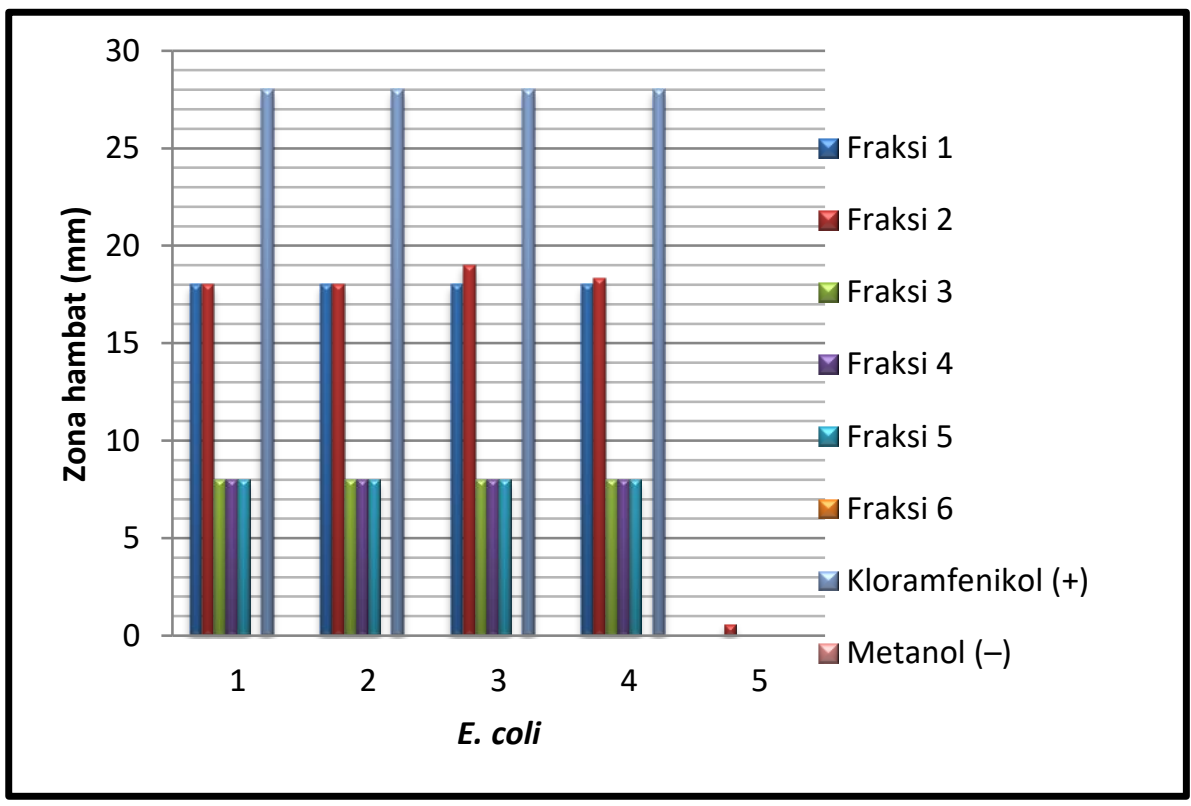

Gambar 5. Diagram rerata diameter zona hambat fraksi ODS spons Agelas sp. pada pertumbuhan bakteri E. coli. 


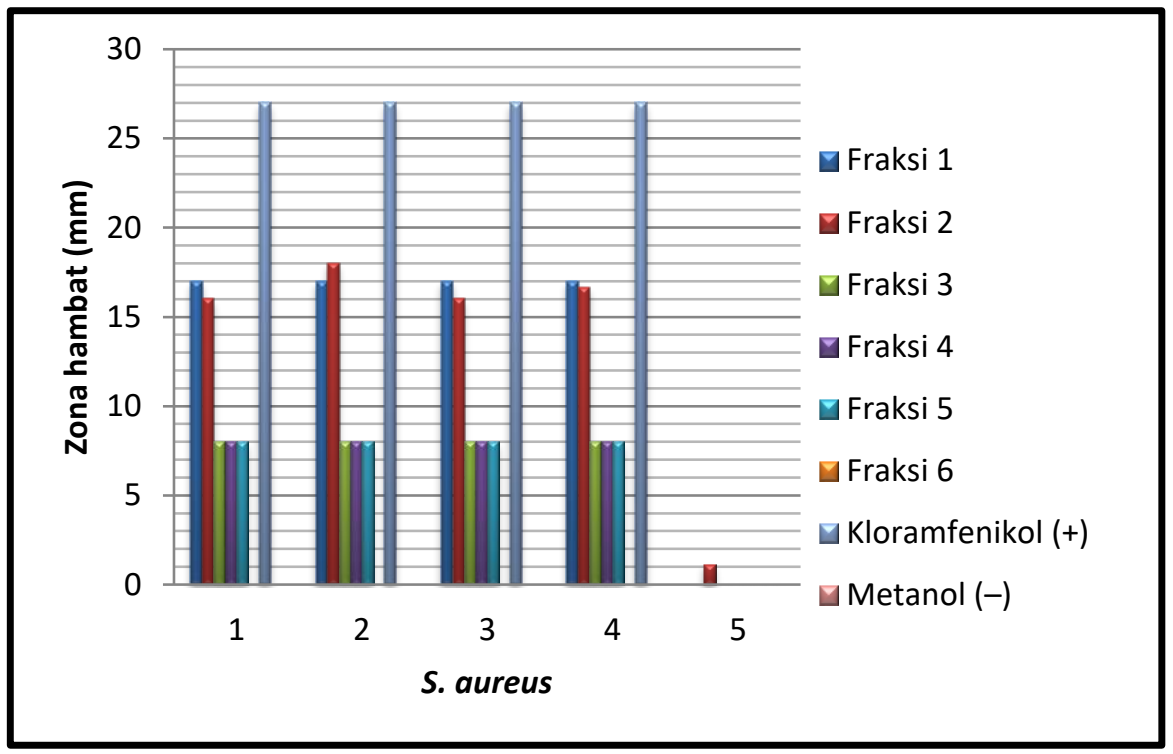

Gambar 6. Diagram rerata diameter zona hambat fraksi ODS spons Agelas sp. pada pertumbuhan bakteri $S$. aureus.

\section{KESIMPULAN}

1. Ekstrak spons Agelas sp. berhasil diperoleh sebanyak 6,9656 gram melalui proses maserasi dengan pelarut etanol dan evaporasi.

2. Pemisahan ekstrak kasar spons Agelas sp. menggunakan teknik (reversed phase) kromatografi kolom diperoleh sebanyak 6 fraksi dengan konsentrasi perbandingan metanol dan aquades, dengan berat kering yakni 3,0925 gram (fraksi 1), 0,2312 gram (fraksi 2), 0,1548 gram (fraksi 3), 0,0231 gram (fraksi 4), 0,0067 gram (fraksi 5), dan 0,0200 gram (fraksi 6).

3. Fraksi ODS 1-5 ekstrak spons Agelas sp. memiliki bioaktivitas antibakteri terhadap pertumbuhan bakteri $S$. aureus dengan diameter $17,0 \mathrm{~mm}$ (fraksi 1), 16,7 mm (fraksi 2), 8,0 mm (fraksi 3), 8,0 mm (fraksi 4), dan 8,0 mm (fraksi 5). Kemudian pada bakteri $E$. coli dengan diameter zona hambat 18,0 $\mathrm{mm}$ (fraksi 1), 18,3 mm (fraksi 2), 8,0 $\mathrm{mm}$ (fraksi 3), 8,0 mm (fraksi 4), dan 8,0 $\mathrm{mm}$ (fraksi 5).

\section{DAFTAR PUSTAKA}

Atlas, R. M., Snyder, J. W. 2005. Handbook of Media for Enviromental Microbiology Second
Edition. Taylor and Francis Group, USA. pp. 34-38.

Bara, R. 2007. Study Metabolic Rate and Metabolism in the Sponge Haliclona oculata Using Different ${ }^{13} \mathrm{C} \quad$ Labeled Substrates. Thesis. Wageningen University, Netherlands. p. 47.

Blunt, J. W., Copp, B., Keyzers, R., Munro, R. A., Prinsep, M. H. G. 2015. Marine natural products. Nat. Prod. Rep. $32 . \quad$ DOI 10.1039/c4np00144c. pp 116-211.

Firmansyah, E. W. 2014. Biokimia dan Analisis Pangan Kromatografi Kolom. Jurnal Fakultas Teknologi Pertanian UNBRAW, Malang. Hal. 10-12.

Haedar, B., Sadarun, Palupi. 2016. Potensi Keanekaragaman Jenis dan Sebaran Spons di Perairan Pulau Saponda Laut Kabupaten Konawe. FPIK Universitas Halu Oleo, Kendari. Sapa Laut, 1:1-9.

Madigan, M. 2005. Brock Biology of Microorganisme, London: Prentice Hall. pp 753. 
Ortez, J. H. 2005. Disk Diffusion Testing in Manual of Antimicrobial Susceptibility testing. Marie B. Coyle (Coord. Ed). American society for Microbiology.

Pedersen, S. F., Myers, A. M. 2011. Understanding The Principles Of Organic Chemistry A Laboratory Course. Brooks/Cole, Cengage Learning, Belmont, USA. pp 121122.

Rares, J. J. 2015. Manajemen Pengelolaan Taman Nasional Bunaken Oleh Pemerintah Provinsi Sulawesi Utara. Jurnal LPPM. UNSRAT, Manado. Hal. 1-2.

Rahman, H., Usman, A., Ahmad. 2014. Isolasi, Identifikasi dan Uji Bioaktivitas Metabolit Sekunder Ekstrak Kloroform Spons Petrosia alfiani Dari Kepulauan Barrang Lompo. FMIPA UNHAS, Makassar. Hal. 1-5.

Rompas, R. 2011. Farmakognosi Laut (Sumber Baru Ekonomi Kelautan). Dewan Kelautan Indonesia, Jakarta. .

Schunack, W., Mayer, K., Haake, M. 1990. Senyawa Obat. Wattimenna JR, Subito, penerjemah. UGM Press, Yogyakarta. Edisi ke-2..

Temidayo, A. R. 2013. Extraction and Isolation of Flavonoids Present in the Methanolic Extract of Leaves of Acanthospermum Hispidium Dc. Global Journal of Medicinal Plant Research, Nigeria. pp 6-8.

Wewengkang, D., Sumilat, D. A., Rotinsulu, H. 2014. Karakterisasi dan Bioaktif Antibakteri Senyawa Spons Haliclona sp. Dari Teluk Manado. Jurnal LPPM, 1(1):73-79. 